\section{Asexual Embryogenesis and Plant Regeneration from Male Catkins of Quercus}

\author{
V.M. Gingas \\ Plant Tissue Culture Laboratory, Southern State Community College, 200 \\ Hobart Drive, Hillsboro, $\mathrm{OH} 45133$
}

Additional index words. oak, tissue culture, hardwood, forest tree

Abstract. Partially expanded male catkins of swamp white oak (Quercus bicolor Willd.) and red oak (Quercus rubra L.) were cultured on Murashige and Skoog (MS) medium supplemented with BA or 2,4-D. Explants on 2,4-D produced a yellow embryogenic callus originating from the junction of the pedicel and peduncle. Subsequent transfers to MS with BA and then MS without growth regulators resulted in callus proliferation. After 10 to 14 weeks in culture, white embryoids developed from the callus of Q. bicolor. Separated and individually cultured embryoids underwent direct, repetitive embryogenesis. Upon transfer to 1/2-strength MS, embryoid germination and plant regeneration occurred. Callus of $Q$. rubra degenerated after 5 months in culture, failing to yield embryogenic structures. Chemical names used: dichlorophenoxyacetic acid (2,4D); benzyladenine (BA).

Successful regeneration of tree species via asexual embryogenesis has been achieved most frequently when embryonic tissues were used as explant material (Tulecke, 1987). This holds true for the genus Quercus (Gingas and Lineberger, 1989). Genotypes of such regenerates are usually unknown, and the phenotypes are uncertain for many years. Successful vegetative micropropagation of adult oaks has been limited (Manzanera and Pardos, 1990). Therefore, this study was conducted to evaluate the embryogenic potential of oak floral tissues.

Staminate catkins were collected at the semipendent stage of development (Sharp and Chisman, 1961) from individual trees of swamp white oak and red oak, representatives of the Lepidobalanus and Erythrobalanus subgenera, respectively (Stair, 1964). Whole catkins were disinfested with a $0.5 \%$ sodium hypochlorite and $0.5 \%$ Alconox solution for $15 \mathrm{~min}$ followed by two sterile, distilled water rinses. Ten whole catkins and 15 catkin pieces of each species were placed on a modified MS (Murashige and Skoog, 1962) medium containing $200 \mathrm{mg}$ casein hydrolysate/liter and 3\% sucrose supplemented with either BA at $1 \mathrm{mg} \cdot \operatorname{liter}^{-1}$ or 2,4-D at 1 $\mathrm{mg} \cdot$ liter $^{-1}$. No basal medium or medium supplemented with $<1 \mathrm{mg} 2,4-\mathrm{D} /$ liter was included in this study, based on previous ineffectiveness (unpublished data). The $\mathrm{pH}$ of the medium was adjusted to 5.7 before autoclaving (121C for $20 \mathrm{~min}$ ) and $0.25 \% \mathrm{Gel}-$ rite (Scott Laboratories, Atlanta) was added. Cultures were subjected to darkness for 48 $\mathrm{h}$ and then placed under $30 \mu \mathrm{mol} \cdot \mathrm{m}^{-2} \cdot \mathrm{s}^{-1}$ of continuous illumination provided by coolwhite fluorescent lamps.

Received for publication 16 Oct. 1990. The cost of publishing this paper was defrayed in part by the payment of page charges. Under postal regulations, this paper therefore must be hereby marked advertisement solely to indicate this fact.
About $75 \%$ of all explants of both species were lost to fungal contamination, especially intact catkins. Increasing the disinfestation time or increasing the sodium hypochlorite concentration resulted in explant necrosis. After 3 weeks on the 2,4-D medium, explants of both species yielded a yellow callus that proliferated from the base of individual flowers on the peduncle (Fig. la). No callus resulted from catkins cultured initially on BA. After 4 to 6 weeks on 2,4-D, yellow callus from both species was transferred to MS or MS + $1 \mathrm{mg}$ BA/liter. Only swamp white oak callus transferred to MS containing BA increased in mass and turned a glistening yellowish-tan. All other callus became dull yellow and, finally, necrotic after 4 months in culture. After 6 to 8 weeks on BA, swamp white oak callus transferred to MS without growth regulators produced opaque, white embryoids (Fig. lb), and repetitive embryogenesis directly from the surface of these embryoids has continued for more than 1.5 years. When normal, polar embryoids were separated and cultured on 1/2-strength MS without growth regulators, $\approx 20 \%$ germinated and developed roots and/or shoots resembling normal seedling growth. Neither a chilling treatment (4C for 30 days) nor a desiccation treatment (placement in empty petri plates for 14 days) enhanced germination. Two plantlets have been transplanted into a soilless potting medium (Fig. 1c). However, successful acclimation did not occur after 6 months.

The embryogenic pathway described by Gingas and Lineberger (1989) using zygotic embryo explants of $Q$. rubra differs from that presented here. In the former study, embryoids initially arose directly from the zygotic embryos. Then, after 10 to 12 weeks in culture, embryogenic callus proliferated from explants, which, in turn, produced embryoids. Also, a desiccation treatment was required for the development of embryoids

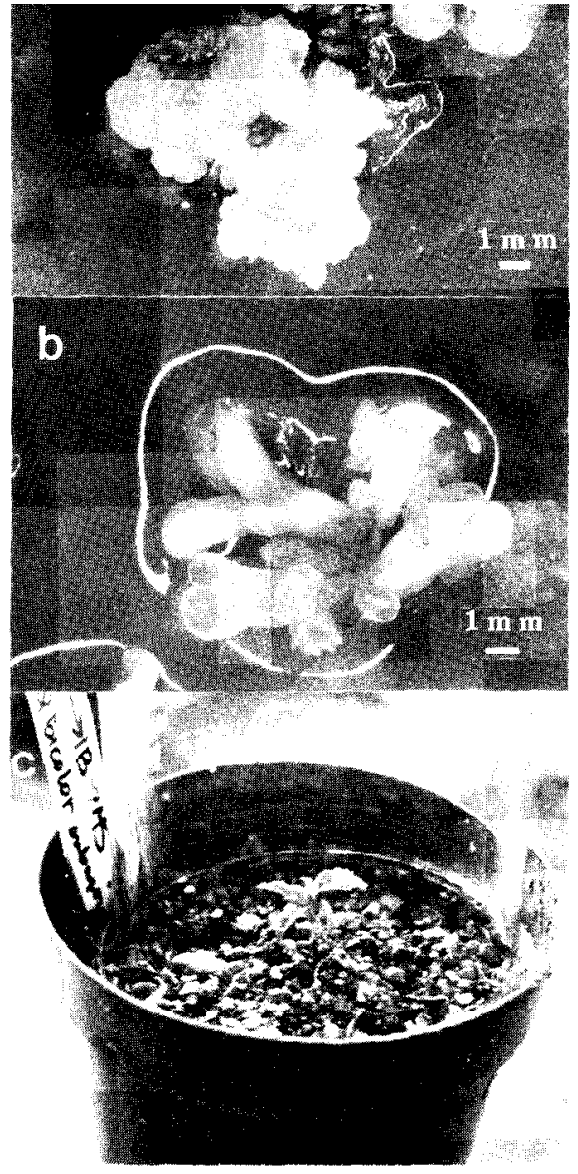

Fig. 1. Developmental stages of asexual embryogenesis in Quercus bicolor. (a) Callus arising from the catkin; (b) embryoids and embryoid clumps; (c) plantlet being acclimated to nonsterile conditions.

into plants. This discrepancy in embryoid germination requirements may parallel that found in the zygotic counterparts of these two oak species.

Krul and Worley (1977) were able to regenerate hybrid grapes from callus derived from flower clusters, although the tissues of origin were unidentified. Peduncles of $\mathrm{Car}$ ica stipulata L. gave rise to embryogenic callus that subsequently developed into plants (Litz and Conover, 1980). Recently, callus derived from filaments of mature Aesculus hippocastanum L. trees produced somatic embryos (Jorgensen, 1989). This evidence, coupled with the preliminary results of the oak study, clearly show that the regenerative capacity of woody plant floral tissues should be further investigated.

\section{Literature Cited}

Gingas, V.M. and R.D. Lineberger. 1989. Asexual embryogenesis and plant regeneration in Quercus. Plant Cell Tissue Organ Cult. 17:191203.

Jorgensen, J. 1989. Somatic embryogenesis in Aesculus hippocastanum L. by culture of filament callus. J. Plant Physiol. 135:240-241. 
Krul, W.R. and J.F. Worley. 1977. Formation of adventitious embryos in callus cultures of 'Seyval', a fresh hybrid grape. J. Amer. Soc. Hort. Sci. 102:360-363.

Litz, R.E. and R.A. Conover. 1980. Somatic embryogenesis in cell cultures of Carica stipulata. HortScience 15:733-735.

Manzanera, J.A. and J.A. Pardos. 1990. Micro- propagation of juvenile and adult Quercus suber L. Plant Cell Tissue Organ Cult. 21:1-8.

Murashige, T. and F. Skoog. 1962. A revised medium for rapid growth and bioassays with tobacco tissue cultures. Physiol. Plant. 15:479497.

Sharp, W.M. and H.H. Chisman. 1961. Flowering and fruiting in the white oaks. I. Staminate flowering through pollen dispersal. Ecology 42:365-372.

Stair, G.R. 1964. Microsporogenesis and embryogenesis in Quercus. Bot. Gaz. 125:155-121.

Tulecke, W. 1987. Somatic embryogenesis in woody perennials, p. 61-91. In: J.M. Bonga and D.J. Durzan (eds.). Cell and tissue culture in forestry. vol. 2. Marinus Nihoff, Boston. 